Univerzitet u Beogradu
Poljoprivredni fakultet
Institut za poljoprivrednu tehniku
Naučni časopis
POLJOPRIVREDNA TEHNIKA
Godina XLV
Broj 2, 2020.
Strane: $21-27$
UDK: 338.43.1.
$\begin{array}{r}\text { University of Belgrade } \\ \text { Faculty of Agriculture }\end{array}$
Scientific Journal
AGRICULTURAL ENGINEERING
Year XLV
No. 2, 2020.
pp: $21-27$

\title{
IMPORTANCE OF PREPARING THE AUDIT REPORT FOR THE TOP MANAGEMENT OF AN AGRICULTURAL ENTERPRISE
}

\author{
Maja Jokić ${ }^{1}$, Dragana Popović ${ }^{2}$, Slobodan Popovic $\mathbf{c}^{3 *}$ \\ ${ }^{1}$ PhD student, Faculty of Tehnical Sciences, University of Novi Sad, \\ Square Dositej Obradović 6, 21000 Novi Sad, R.Serbia \\ ${ }^{2}$ Student, Faculty of Economics Subotica, University of Novi Sad, \\ Segedinski put 9-11, 24000 Subotica, R.Serbia \\ ${ }^{3}$ PCC ,, City Greenery Novi Sad“", Temerinski put bb, 21000 Novi Sad, R.Serbia
}

\begin{abstract}
Introduced audit in business and management of an agricultural enterprise can contribute to improving the management of the enterprise. This can reduce the risk to the top management of an agricultural enterprise. Management should be seen as an organ of the enterprise which is constantly looking for improvement of the management of the enterprise. The processes for establishing audit mechanisms should serve to improve the overall management of the agricultural enterprise. Audit can provide full support to management. The authors point out that their contribution in this paper is primarily aimed at identifying the first stage in the process of forming an audit control mechanism in the company, more specifically, the stage of preparation of the audit report submitted to top management and on the basis of which it further makes management decisions.
\end{abstract}

Key words: audits, process management, agriculture

\section{INTRODUCTION}

Farm management requires top management to find new innovative approaches that can help them make important business decisions [1], all with a view to making valid business decisions in agricultural businesses, [2] which can generate many benefits [3] in business.

*Corresponding author Email: slobodan.popovic49@gmail.com 
Agricultural businesses should use in their regular operations the various analyzes applied by auditors in their work [4], as this generally improves the work of the entire agricultural sector [5], [6], [7].

The audit of an agricultural enterprise begins with the design and preparation of an audit report for performing the audit work in the enterprise [8], [9]. This practically means that the practical functioning of the agricultural enterprise can be improved [10], [11], [12] if the audit reports are properly designed by the auditor.

All audit processes should respect processes based on the standardization of top management [13]. The auditor's behavior thus adopted results in a change in the overall behavior within the branches, that is, a change in socio-economic behavior within the economy as a whole [14].

Therefore, it can be observed that it is important for the audit business to form properly started and prepared audit reports in the company [16], [17], [18].

\section{MATERIAL AND METHODS}

The authors used generally accepted models of management in an agricultural enterprise to produce the work, which were based on the use of top management reporting by highly professionally trained personnel, more specifically by audit personnel.

Audit should be seen as an aid to top management in agricultural enterprises, and in this paper the authors draw attention to the importance of using auditors' reporting. In this regard, they have provided a possible and useful model for the sequence of events in agricultural companies, which is presented by the author in Figure 1 in this study, where the importance of audit reporting is emphasized.

Modern business requires modeling that involves innovative approaches by top management, which requires new approaches, which is achieved by a greater degree of application of the audit profession.

In this paper, the authors emphasize the importance of implementing audit reporting so as to improve substantially the achievement of job improvements, but also with the reduction of possible operational risks in the regular operations of a large number of agricultural enterprises.

\section{RESULTS AND DISCUSSION}

The authors point out that audit as a model of the method of improving the performance of an agricultural enterprise is an important factor business success in the operation of the agricultural enterprise itself. Audit at the stage of preparation of audit reporting in agricultural enterprises should include three parts:

- Audit report functions;

- the types of audit reports and their alternatives;

- Guidance on the structure and content of audit reports. 
The audit report should provide the top management of the agricultural enterprise with the confirmation of the adequacy of the system under review as well as the basis for the overall confirmation of the adequacy of the internal control system communicated to the management through the report.

It is very important to keep in mind that the audit report is the only tangible product of the audit and, as such, it is a "showcase" of the internal audit. It represents the sum of the planning, time and effort invested in a single audit and reflects the quality and thoroughness of the audit.

The quality of the report will significantly affect the image that the organization's management will have of internal audit. An inadequate report can invalidate both the best audit work and the best conclusions. In addition, the report may adversely affect the reputation and status of the internal audit.

The purpose and functions of the audit report.

The main objectives of the audit report are:

- report on the problems identified and the causes of those problems; explain the effects and consequences of these problems and quantify them where necessary;

- to measure performance and to identify areas where greater efficiency and effectiveness can be achieved and loss eliminated;

- convince management of the need for change;

- $\quad$ propose practical and cost-effective solutions;

- $\quad$ Provide a basis for monitoring the implementation of appropriate measures.

There are three basic functions of an audit report. Firstly, the report is a document that should encourage action - a report that does not encourage action is a waste of time for everyone involved in the audit. In order to result in appropriate action being taken, the report should provide the user with a concise and objective assessment of controls in the area under review and highlight any significant weaknesses identified.

The report should also report on the impact of these weaknesses on the level of controls. Also, a report to the management indicates that something needs to be done about this:

- through explaining the risks,

- Where possible, quantify those risks and any potential benefits.

Secondly, the report is a formal, permanent record of the audit work performed and the conclusions obtained, as well as the level of controls that exist in a particular area at a particular time. Finally, a good report, demonstrating the professionalism and competence of the auditor, testifies to the objectivity and independence of the internal audit and demonstrates that the auditors can help improve efficiency and effectiveness.

A general management model based on the author's previous point of view is given in the form of a general model by the representation of Figure 1 by the author. 


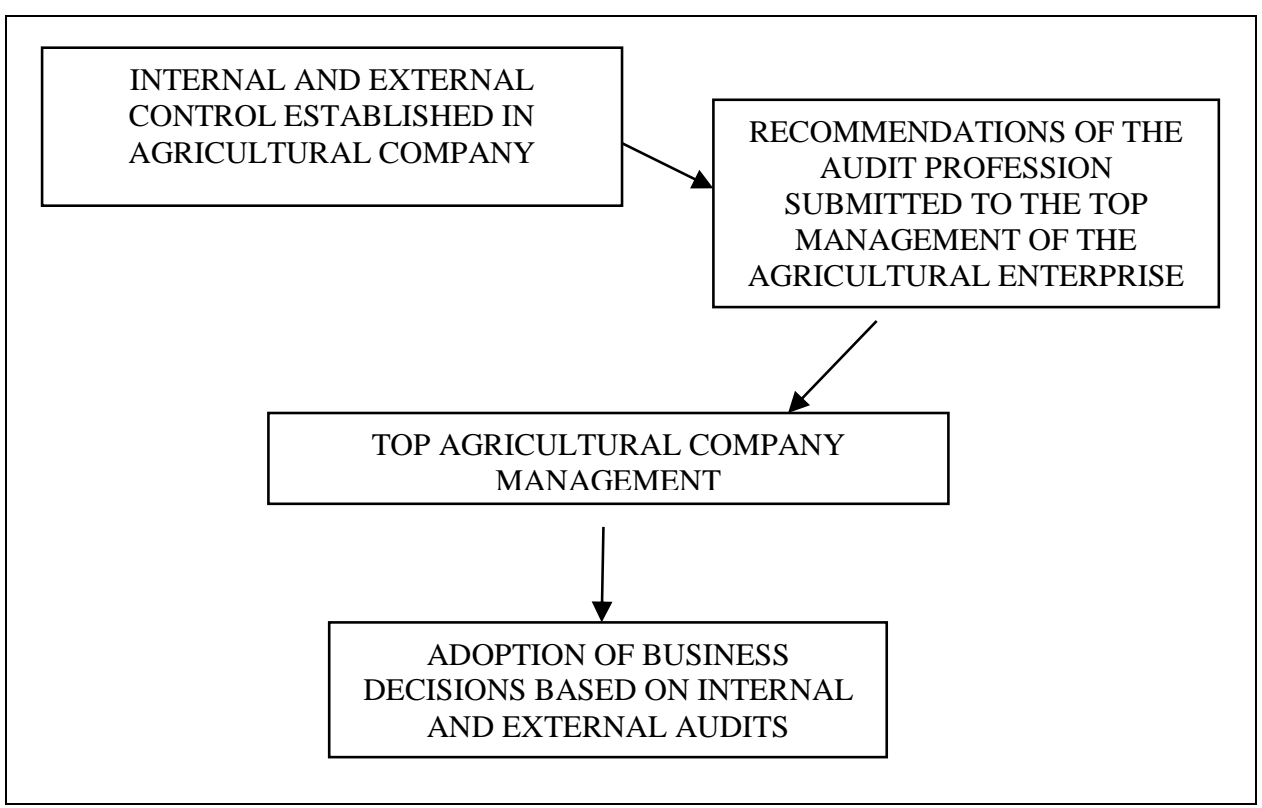

Fig. 1. Model of harmoniously introduced audit model in an agricultural enterprise based on top management decision making with respect to the recommendations of the audit profession

The report, as a formal record of the results of the audit, should be made in writing. There are two basic types of audit reports-the Standard Report and the Audit Memorandum.

A standard report is the type of report that is most commonly used. It consists of three main parts: a summary, an action plan (action plan) and a detailed report.

The MOU is usually shorter than the standard report and serves:

- For prompt and specific reviews carried out at the request of management to obtain information on the results of subsequent audits;

- when only minor audit findings emerge;

- as a transitional report in longer audits.

As an alternative to the audit report, there is also the possibility of an oral presentation, which entails a formal presentation of the audit findings, as well as a discussion of the measures that management should take. The advantages and disadvantages of reports and presentations are presented in the following table. The authors gave an example of the presentation method in Table 1. 
Table 1. The method that implements the presentation in reporting to the top management of an agricultural enterprise

\begin{tabular}{|c|c|c|}
\hline $\begin{array}{l}\text { Presentation } \\
\text { method }\end{array}$ & Advantages & Deficiency \\
\hline Presentation & $\begin{array}{l}\text { Interactive } \\
\text { Flexible } \\
\text { Easier acceptance } \\
\text { Helps to consider difficult questions } \\
\text { and solutions } \\
\text { May increase the chance of } \\
\text { enforcement } \\
\text { Contributes to focusing on priority } \\
\text { issues } \\
\text { Internal audit can influence the } \\
\text { action taken }\end{array}$ & $\begin{array}{l}\text { Not all evidence can be presented } \\
\text { It can lead to difficulties in presenting } \\
\text { complex data which can lead to } \\
\text { misunderstandings } \\
\text { Presentation skills and active } \\
\text { involvement of two people are required } \\
\text { Good preparation is necessary } \\
\text { Possibility of dominance of one person } \\
\text { or a particular problem } \\
\text { The user can still request a report }\end{array}$ \\
\hline $\begin{array}{l}\text { Standard } \\
\text { Report }\end{array}$ & $\begin{array}{l}\text { Good for detailed reporting and } \\
\text { complex data } \\
\text { It can provide general information } \\
\text { and context } \\
\text { The evidence is immediately } \\
\text { available to the reader } \\
\text { Some users find reports more } \\
\text { authoritative }\end{array}$ & $\begin{array}{l}\text { They require more preparation time } \\
\text { Long reports can remain unread until } \\
\text { the end } \\
\text { Sometimes hard to accept } \\
\text { They may be untimely presented due to } \\
\text { delays in preparation }\end{array}$ \\
\hline
\end{tabular}

The internal audit manager should define the precise structure of the audit report. It is important that every organization has a distinctive reporting style. This helps managers to use and understand audit reports more easily, and helps create an image of the internal audit service.

Standard audit reports should usually include the following:

- Report cover / cover;

- The content;

- Summary;

- Activity plan / Recommendation proposal;

- Detailed report;

- Attachments / Annexes.

The audit memorandum includes:

- Introduction;

- Conclusion;

- A series of separate paragraphs, where detailed findings and recommendations have adequate headings.

The following are instructions on the content of each chapter / section in the standard audit report.

The cover/cover of the report should include the title of the report, date of preparation and number of the report. 
Some audit services have a logo on the front page/cover. It would be a good idea to consider using different cover colors for different types of revisions (systems, VFM value, etc.).

\section{CONCLUSIONS}

In this paper, the authors emphasized the importance of drawing up an audit report in the ordinary course of business of an agricultural enterprise, which should be applied by top managers of enterprises in order to achieve better business results.

The contribution of the author is reflected in the highlighting of a model that respects the movement of top management's business decision-making while respecting the auditing profession.

In addition, the authors highlighted the general model of implementation of multiple types of audit report that can serve more agricultural enterprises in the ordinary course of business as well as the structure of the audit report itself.

The application of the structure of the audit profession in reporting is of great importance and the authors of the paper have highlighted the basic possible structures of the report.

\section{BIBLIOGRAPHY}

[1] Wyatt A. 2004. Accounting professionalism: they just don't get it !. Accounting Horizons.

$$
\text { 18. pp. 45-53. }
$$

[2] Northouse, P. 2008. Liderstvo. Beograd. Data Status.

[3] Popović S. 2014. Socio-ekonomski faktori ograničenja razvoja agrara. Monografija. FIMEK, Novi Sad.

[4] Cantino, V. 2009. Korporativno uptravjanje, merenje performansi i normativna usaglašenost sistema internih kontrola. Beograd. Data Status.

[5] Damodaran, A. 2007. Korporativne finansije: teorija i praksa. Podgorica. Modus.

[6] Popović, S., Ugrinović, M., Tomašević, S. 2015. Upravljanje menadžmenta poljoprivrednog preduzeća preko praćenja ukupnih troškova održavanja traktora, Poljop. tehnika No2. pp.101-106.

[7] Popović, S., Ugrinović, M., Tomašević, S. 2015. Management of Agricultural Enterprises by Means of Fair Financial Reporting in Accordance with International Standards of the Finance and Accounting Reporting. CDQM. No 3: 24-30.

[8] Popović, S., Mijić, R., Grublješić, Ž. 2014. Interna kontrola i interna revizija u funkciji menadžmenta. Škola Biznisa. 1., 95-107.

[9] Popović, S., Tošković, J., Majstorović, A., Brkanlić, S., Katić, A. 2015. The importance of continuous audit of financial statements of the company of countries joining the EU. Annals of the „Constantin Brâncuşi” University of Târgu Jiu. Economy Series. Special Issue. pp. 241-246.

[10] Williams, C. 2010. Principi menadžmenta. Data Status. Beograd.

[11] Popović S. 2015. Implementacija heterogenih rizika u radu interne revizije, Revizor 69/2015. Institut za ekonomiku i finansije. Beograd, pp.7-19.

[12] Rodriguez, M., Miguel, Sanchez, L., Cejudo, E. \& Antonio, C. 2019. Variety in local development strategies and employment: LEADER programme in Andalusia. Agric. Econ. Czech. 65: 43-50.

[13] Nowak, A., Janulewicz, P., Krukowski, A. \& Bujanowicz-Haraś, B. 2016. Diversification of the level of agricultural development in the member states of the European Union. Cahiers Agricultures, 25: 55004. DOI: 10.1051/cagri/2016040 
[14] Lee, J. 2019. Regional heterogeneity among non-operating earnings quality, stock returns, and firm value in biotech industry. Agric. Econ. - Czech. 65: 10-20.

[15] Funnell, W.Wade, M. R. Jupe. 2016. Stakeholder perceptions of performance audit credibility. Accounting and Business Research. 46(6): 601-619.

[16] Endaya, K. - Hanefah, M. 2013. Internal Audit Effectiveness: An Approach Proposition to Develop the Theoretical Framework. Research Journal of Finance and Accounting. 4(10): 92-102.

[17] Gaetano, S. \& Lamonaca, E. 2019. On the drivers of global grain price volatility: an empirical investigation. Agric. Econ. - Czech. 65: 31-42.

[18] Daske, H. - Hail, L. - Leuz, C. - Verdi, R. 2008. Mandatory IFRS Reporting Around the

World. Early evidence on the economic consequences. J. of Accounting Research. 46: 1085-1142.

\title{
ZNAČAJ PRIPREME REVIZIJSKOG IZVEŠTAJA ZA TOP MENADŽMENT POLJOPRIVREDNOG PREDUZEĆA
}

\author{
Maja Jokić1 ${ }^{1}$ Dragana Popović², Slobodan Popović ${ }^{3}$ \\ ${ }^{1}$ Student doktorskih studija, Fakultet tehničkih nauka, Univerzitet u Novom Sadu, \\ Trg Dositeja Obradovića 6, 21000 Novi Sad, R.Serbia \\ ${ }^{2}$ Student, Ekonomski fakultet Subotica, University of Novi Sad, \\ Segedinski put 9-11, 24000 Subotica, R.Serbia \\ ${ }^{3} J K P$,, Gradsko Zelenilo Novi Sad“, Temerinski put bb, 21000, Novi Sad, R.Serbia
}

Sažetak: Uvedena revizija u poslovanje i upravljanje poljoprivrednog preduzeća može da doprinese poboljšanju upravljanja preduzeća. Time se može smanjiti rizik po poslovanje top menadžmenta poljoprivrednog preduzeća. Menadžment treba posmatrati kao organ preduzeća koji je u stalnom traganju za poboljšanjem upravljanja preduzeća. Procesi uspostavljanja revizijskih mehanizmama treba da posluže poboljšanju ukupnog upravljanja poljoprivrednog preduzeća. Revizija može da pruži punu podršku menadžmentu. Autori ističu da je njihov doprinos u ovom radu pre svega usmeren na utvrđivanje prve faze $u$ procesu formiranja revizijskog kontrolnog mehanizma $u$ preduzeću, preciznije istaknuto, reč je o fazi pripreme revizijskog izveštaja koji se dostavlja top menadžmentu i na osnovu kojeg on dalje donosi odluke vezane za upravljanje.

Ključne reči: revizija, upravljanje procesima, poljoprivreda

Prijavljen:

Submitted:

25.12.2019.

Ispravljen:

Revised:

05.05 .2020

Prihvaćen:

Accepted:

30.05.2020. 